\title{
IMPLEMENTASI PENDEKATAN SAINS-TEKNOLOGI-MASYARAKAT (STM) DALAM PEMBELAJARAN MOTOR BAKAR PADA MAHASISWA JURUSAN TEKNIK MESIN POLITEKNIK NEGERI BALI
}

Oleh: I Putu Darmawa*)

\section{Abstrak}

Tujuan penelitian ini untuk mengetahui: perbedaan hasil belajar motor bakar mahasiswa yang mengikuti pendekatan STM dengan hasil belajar motor bakar mahasiswa yang mengikuti pendekatan konvensional. Tujuan lainnya adalah ingin mengetahui apakah ada perbedaan hasil belajar motor bakar pada mahasiswa yang diajar menggunakan pendekatan STM dengan mahasiswa yang diajar menggunakan pendekatan konvensional setelah diadakan pengendalian terhadap variabel bakat mekanik.

Penelitian ini merupakan penelitian eksperimen semu dengan menggunakan rancangan The Posttest-Only Control Group Design dengan melibatkan sample sebanyak 46 orang mahamahasiswa Politeknik Negeri Bali dan diambil secara random sampling. Data dikumpulkan menggunakan tes hasil belajar dan tes bakat mekanik. Data dianalisis secara statistik deskriptif dan statistik inferensial yaitu analisis kovariansi (anakova) Hasil analisis data menunjukan bahwa ada perbedaan yang signifikan antara hasil belajar motor bakar yang diajar dengan menggunakan pendekatan STM dengan pendekatan konvensional. Setelah bakat mekanik dikendalikan, ada perbedaan yang signifikan antara hasil belajar motor bakar yang diajar menggunakan pendekatan STM dengan pendekatan konvensional. Bakat mekanik tidak memberikan kontribusi terhadap efektivitas penerapan pendekatan STM dalam pembelajaran motor bakar

Kata kunci: Pendekatan STM, Hasil Belajar Motor Bakar, Politeknik

\section{A. PENDAHULUAN}

\section{Latar Belakang}

Jurusan teknik mesin merupakan salah satu jurusan yang di lingkungan Politeknik Negeri Bali. Memiliki visi, terciptanya tenaga profesional di bidang teknologi yang berwawasan Internasional berdasarkan Ketuhanan Yang Maha Esa. Motor bakar adalah salah satu mata pelajaran yang diberikan kepada mahasiswa jurusan teknik mesin selama 1 semester dalam alokasi waktu 4 SKS.
Fungsi dan tujuan pembelajaran motor bakar adalah untuk mewujudkan mahasiswa yang menguasai konsepkonsep motor bakar dan menerapkannya dalam upaya memecahkan masalahmasalah yang berhubungan dengan iptek dan dalam kehidupan sehari-hari di masyarakat. Mata kuliah ini merupakan salah satu mata kuliah keahlian yang di ajarkan kepada mahasiswa jurusan teknik mesin, banyak berkaitan dengan penerapan konsep sains pada teknologi.

*) Ir. I Putu Darmawa, M.Pd. Staf Dosen Teknik Mesin Politeknik Negeri Bali 
Selama ini proses pembelajaran motor bakar di jurusan teknik mesin, terfokus pada dosen dan mengandalkan kemampuan seorang dosen dalam menyampaikan konsep yang berhubungan motor bakar. Pendekatan dan metode pembelajaran yang digunakan oleh dosen didominasi oleh metode kuliah seperti metode ceramah dan pemberian tugas. Realita sementara ini, tingkat pencapaian tujuan pembelajaran motor bakar di Politeknik disinyalir masih relatif rendah. Akibatnya, pemahaman mahasiswa terhadap konsep- konsep otomotif secara menyeluruh juga masih rendah.

Gambaran keadaan di atas menunjukkan betapa pentingnya suatu upaya mencari alternatif untuk meningkatkan hasil belajar, khususnya pada latar pembelajaran motor bakar di jurusan teknik mesin. Salah satu bentuk upaya yang dimaksud adalah pada ranah yang dekat dengan upaya memfasilitasi belajar mahasiswa yaitu aspek alternatif strategi pembelajaran. Pencarian strategi alternatif yang dimaksud mengacu kepada faktor penyebab rendahnya hasil belajar. Faktor umum yang menyebabkan rendahnya hasil belajar adalah faktor internal dan eksternal mahasiswa. Faktor eskternal mencakup strategi pembelajaran, sedangkan faktor internal salah satu diantaranya bakat mekanik. Dengan demikian dipandang perlu untuk mengupayakan suatu strategi pembelajaran yang tepat, yaitu pendekatan pembelajaran yang dapat mengedepankan aktivitas mahasiswa. Pendekatan pembelajaran seperti ini dan didukung oleh teori belajar yang tepat akan dapat meningkatkan kualitas hasil proses pembelajaran. Abbas (2005) menyatakan bahwa, banyak faktor mempengaruhi hasil belajar, salah satu diantaranya ketidak tepatan menggunakan model pembelajaran yang digunakan dosen di kelas. Zamroni (2000) menjelaskan bahwa, kualitas pendidikan, dalam arti kemampuan yang dimiliki oleh para mahasiswa sangat tergantung pada kualitas proses pembelajaran yang berlangsung. Artinya setiap upaya yang bertujuan untuk meningkatkan kualitas pendidikan harus lewat peningkatan proses pembelajaran. Oleh karena itu, perlu untuk mengupayakan suatu strategi pembelajaran yang tepat, yaitu model pembelajaran yang dapat mengedepankan aktivitas mahasiswa dan berorientasi pada isu-isu yang berkembang dimasyarakat. Model pembelajaran yang dimaksud yaitu model pembelajaran dengan pendekatan sainsteknologi-masyarakat (STM)

Pendekatan pembelajaran yang banyak diteliti dan terbukti dapat meningkatkan hasil belajar mahasiswa adalah strategi pembelajaran berpendekatan konstruktivis salah satu diantaranya yakni pendekatan Sains-Teknologi-Masyarakat (STM). Pendekatan ini merupakan upaya pembelajaran sains di sekolah yang menekankan pada konteks pembelajaran dan multi-dimensi atau domain hasil belajar mahasiswa (dengan mengintegrasikan domain konsep, keterampilan proses, kreativitas, sikap, nilai-nilai, dan penerapan dalam pembelajaran dan penilaian) serta keterkaitan antar bidang studi/kurikulum (pendekatan terpadu atau multidisipliner). Disamping itu, dalam pendekatan ini mahasiswa dibiasakan untuk bersikap peduli akan masalahmasalah sosial dan lingkungan yang berkaitan dengan iptek (Adnyana, 2004).

Yager (1993) menyatakan bahwa salah satu tujuan pokok dari Pendekatan STM adalah mengaktifkan mahasiswa dalam kegiatan pemecahan isu-isu/masalahmasalah yang telah diidentifikasi.

Pendekatan konvensional merupakan pendekatan pembelajaran yang biasa dilakukan dosen dalam proses belajar mengajar di dalam kelas. Pada pembelajaran konvensional, proses belajar mengajar lebih diarahkan pada "aliran informasi" atau "trannsfer" pengetahuan dari dosen ke mahasiswa. Konsep yang diterima mahasiswa hampir semuanya berasal dari "apa kata dosen". Dosen menganggap belajar adalah semata-mata mengumpulkan atau menghafalkan fakta-fakta yang tersaji dalam bentuk informasi atau materi 
pelajaran. Proses pembelajaran cendrung hanya mengantarkan mahasiswa untuk mencapai tujuan untuk mengejar target kurikulum.

Dantes (2001) menyatakan bahwa, proses belajar pada hakekatnya merupakan inti dari proses pendidikan secara keseluruhan. Proses ini dipengaruhi oleh faktor internal dan eksternal atau pengaruh interaksi kedua faktor itu. Bakat mekanik salah satu faktor internal merupakan kemampuan potensial yang dimiliki setiap individu mahasiswa dalam memahami cara kerja alat, mesin dan gerakan sederhana. Strategi pembelajaran merupakan salah satu faktor internal yang mempengaruhi hasil belajar. Berdasarkan ini perlu dikaji efektivitas model pembelajaran STM terhadap hasil belajar motor bakar ditinjau dari bakat mekanik.

\section{Rumusan Masalah}

Pokok masalah yang dikaji dalam penelitian ini, yaitu: 1) apakah ada perbedaan hasil belajar motor bakar pada mahasiswa yang diajar menggunakan pendekatan STM dengan mahasiswa yang diajar menggunakan pendekatan konvensional?, dan 2) apakah ada perbedaan hasil belajar motor bakar pada mahasiswa yang diajar menggunakan pendekatan STM dengan mahasiswa yang diajar menggunakan pendekatan konvensional setelah diadakan pengendalian terhadap variabel bakat mekanik?

\section{Tujuan Penelitian}

Tujuan penelitian adalah, untuk mengetahuai: 1) perbedaan hasil belajar motor bakar pada mahasiswa yang diajar menggunakan pendekatan STM dengan mahasiswa yang diajar menggunakan pendekatan konvensional, dan 2) perbedaan hasil belajar motor bakar pada mahasiswa yang diajar menggunakan pendekatan STM dengan mahasiswa yang diajar menggunakan pendekatan konvensional setelah diadakan pengendalian terhadap variabel bakat mekanik.

\section{B. KAJIAN LITERATUR}

1. Hakikat Mata Kuliah Motor Bakar Motor bakar adalah penggerak mula yang mengubah energi kimia bahan bakar minyak (hidro karbon) menjadi energi kalor Depdiknas (2004). Mata kuliah motor bakar merupakan salah satu mata kuliah pada kelompok Mata Keahlian dan Keilmuan (MKK), diberikan di semester IV jurusan tekni mesin Politeknik Negeri Bali. Tujuan Instruksional mata kuliah motor bakar, yaitu mahamahasiswa mampu menjelaskan: 1) prinsip kerja internal combution engine, 2) fungsi dari komponen-komponen utama motor bakar, dan 3) menjelaskan proses kerja pembakaran pada motor bakar. Tujuan khususnya yaitu, mahamahasiswa mampu menjelaskan cara kerja motor bakar 4 langkah dan 2 langkah, siklus ideal dan aktual motor bakar, sistem pengapian, sistem pendinginan, sistem pelumasan, dan sistem bahan bakar bensin dan diesel.

Mata kuliah ini diberikan untuk menunjang mata kuliah praktek perawatan dasar dan praktek motor bakar. Pendukungnya adalah mata kuliah Thermodinamika. Materi pembelajaran motor bakar meliputi: 1) pendahuluan mencakup menjelasan definisi motor bakar dan komponen utama motor bakar; 2) bahan bakar dan proses pembakaran; 3) prinsip kerja motor bensin, 4) prinsip kerja motor diesel; dan 4) analisa ganguan dan dan cara mengatasinya.

\section{Hakikat Belajar dan Pembelajaran Menurut Konstruktivisme}

Konstruktivisme merupakan landasan berpikir, bahwa pengetahuan dibangun oleh manusia sedikit demi sedikit yang hasilnya diperluas melalui konteks yang terbatas atau sempit. Pengetahuan bukanlah seperangkat fakta-fakta, konsep, atau kaidah yang siap untuk diambil dan diingat. Manusialah yang harus mengkonstruksinya dan memberi makna melalui pengalaman nyata. Menurut teori belajar konstruktivisme, pengertahuan tidak dapat dipindahkan 
begitu saja dari pikiran dosen ke pikiran mahamahasiswa. Artinya, bahwa mahasiswa harus aktif secara mental membangun struktur pengetahuannya berdasarkan kematangan kognitif yang dimilikinya (Nurhadi, 2002 dan Hamzah, 2005 )

Teori belajar konstruktivisme menekanan bahwa: 1) peran aktif mahasiswa dalam mengkonstruksi pengetahuan secara bermakna, 2) pentingya membuat kaitan antara gagasan dalam pengkonstruksian secara bermakna, 3) mengaitkan antara gagasan dengan informasi baru yang diterima (Suparno, 1997). Secara spesifik Hudoyo (1990) mengatakan bahwa seseorang akan lebih mudah mempelajari sesuatu bila belajar itu didasari kepada apa yang telah diketahui orang lain. Oleh karena itu, untuk mempelajari suatu materi yang baru, pengalaman belajar yang lalu dari seseorang akan mempengaruhi terjadinya proses belajar tersebut. Selain penekanan tersebut di atas, dalam kaitan dengan pembelajaran dalam teori belajar konstruktivisme, sejumlah aspek yang perlu diperhatikan, yaitu (1) mahasiswa mengkonstruksi pengetahuan dengan cara mengintegrasikan ide yang mereka miliki, (2) pembelajaran menjadi lebih bermakna karena mahasiswa mengerti, (3) strategi mahasiswa lebih bernilai, dan (4) mahasiswa mempunyai kesempatan untuk berdiskusi dan saling bertukar pengalaman dan ilmu pengetahuan dengan temannya (Hanbury, 1996) .

Dalam upaya mengimplementasikan teori belajar konstruktivisme, Tytler (1996: 20) mengajukan beberapa saran yang berkaitan dengan rancangan pembelajaran, sebagai berikut: (1) memberi kesempatan kepada mahasiswa untuk mengemukakan gagasannya dengan bahasa sendiri, (2) memberi kesempatan kepada mahasiswa untuk berfikir tentang pengalamannya sehingga menjadi lebih kreatif dan imajinatif, (3) memberi kesempatan kepada mahasiswa untuk mencoba gagasan baru, (4) memberi pengalaman yang berhubungan dengan gagasan yang telah dimiliki mahasiswa, (5) mendorong mahasiswa untuk memikirkan perubahan gagasan mereka, dan (6) menciptakan lingkungan belajar yang kondusif.

Pembelajaran berorientasi kontruktivisme adalah strategi pembelajaran yang terpusat pada kegiatan mahasiswa dan menekankan pentingnya proses pembentukan pengetahuan oleh mahasiswa itu sendiri berdasarkan pengetahuan yang dimiliki sebelumnya. Penerapan teori ini dalam pembelajaran, akan dapat memberikan keleluasaan mahasiswa dalam mengembangkan konsep yang dikuasainya dan hasilnya bisa lebih efisien atau mungkin bisa lebih sulit, namun mahasiswa dapat mengemukakan ide dan pendapatnya. Mahasiswa mendapatkan keuntungan dalam proses belajar, yaitu mereka lebih berpikir, lebih paham, lebih ingat, lebih yakin, lebih senang dan lebih kooperatif (Subarinah, 2005; Darma, 2006 dan 2007)

Dari beberapa pandangan di atas, dapat disimpulkan bahwa pembelajaran yang mengacu kepada teori belajar konstruktivisme lebih menfokuskan pada kesuksesan mahamahasiswa dalam mengorganisasikan pengalaman mereka. Bukan kepatuhan mahasiswa dalam refleksi atas apa yang telah diperintahkan dan dilakukan oleh dosen. Dengan kata lain, mahasiswa lebih diutamakan untuk mengkonstruksi sendiri pengetahuan mereka melalui asimilasi dan akomodasi.

\section{Model Pembelajaran Sains- Teknologi-Masyarakat}

Model Pembelajaran Sains Teknologi dan Masyarakat (STM) merupakan salah satu pendekatan pembelajaran yang dapat memberikan harapan untuk menciptakan manusia yang berkualitas dan peka terhadap masalah-masalah yang timbul di masyarakat. Pendekatan ini dimaksudkan untuk menjembatani kesenjangan antara kemajuan iptek, membanjirnya informasi ilmiah dalam dunia pendidikan, dan nilai-nilai iptek itu sendiri dalam kehidupan masyarakat sehari-hari (Rusmansyah, 2003). Tujuan dari pendekatan STM adalah untuk membentuk individu yang memiliki literasi 
sains dan teknologi serta memiliki kepedulian terhadap masalah masyarakat dan lingkungannya. Seseorang yang memiliki literasi sains dan teknologi, adalah yang memiliki kemampuan menyelesaikan masalah menggunakan konsep-konsep sains yang diperoleh dalam pendidikan sesuai jenjangnya, mengenal produk teknologi yang ada di sekitarnya beserta dampaknya, mampu menggunakan produk teknologi dan memeliharanya, kreatif membuat hasil teknologi yang disederhanakan dan mampu mengambil keputusan berdasarkan nilai (Poedjiadi, 2005).

Yager (dalam Mariana, 2001: 28) mengajukan empat tahap strategi dalam pembelajaran berorientasi konstruktivisme, yaitu: 1) Invitasi , 2) Eksplorasi, 3) Pengajuan penjelasan dan solusi, dan 4) Menentukan langkah, diterapkan dalam pendekatan SainsTeknologi-Masyarakat. Kondisi ini menandakan bahwa Pendekatan SainsTeknologi-Masyarakat dilandasi oleh teori belajar Konstruktivisme.

Pada hakekatnya pembelajaran sains dengan pendekatan STM, di samping memperoleh pengalaman fisik terhadap obyek dalam pembelajaran, mahasiswa juga memperoleh pengalaman atau terlibat secara mental. Pengalaman fisik, artinya melibatkan mahasiswa atau mempertemukan mahasiswa dengan obyek pembelajaran. Pengalaman mental yang dimaksudkan di sini, adalah memperhatikan imformasi awal yang telah ada pada diri mahasiswa, dan memberikan kebebasan kepada mahasiswa untuk menyusun sendirisendiri informasi yang diperolehnya.

Yager (1992:2-3) menyebutkan NSTA (National Science teachers association) mengajukan sebelas cirri-ciri dalam memerikan pendekatan STM dalam mengajar, antara lain: (1) mahasiswa mengidentifikasikan masalah-masalah yang ada di daerahnya dan dampaknya, (2) menggunakan sumber-sumber setempat (narasumber dan bahanbahan) untuk memperoleh informasi yang dapat digunakan dalam pemecahan masalah, (3) keterlibatan mahasiswa secara aktif dalam mencari informasi yang dapat di terapkan untuk memecahkan masalah-masalah nyata dalam kehidupannya, (4) perluasan untuk terjadinya belajar melebihi periode, kelas, dan sekolah, (5) memusatkan pada pengaruh sains dan teknologi kepada individu mahasiswa, (6) pandangan mengenai sains sebagai content lebih dari skedar yang hanya berisi konsep-konsep dan untuk menyelesaikan ujian, (7) penekanan keterampilan proses sains agar dapat di gunakan oleh mahasiswa dalam mencari solusi terhadap masalahnya, (8) penekanan kepada kesadaran mengenai karier (careef), khususnya karier yang berhubungan dengan sains dan teknologi, (9) memberikan kesempatan kepada mahasiswa umtuk berperan dalam bermasyarakat sebagai usaha untuk memecahkan kembali masalah-masalah yang didentifikasikannya, (10) mementukan proses (ways) sains dan teknologi yang mempengaruhi masa depan, (11) sebagai perwujudan otonomi setiap individu dalam proses belajar (sebagai masalah individu).

Menurut Poedjiadi (1994: 3) penerapan pembelajaran STM dapat mengikuti langkah-langkah, yaitu: 1) dimunculkan isu atau masalah yang digali dari peserta didik, sehingga peserta didik lebih peduli terhadap lingkungannya, sadar terhadap dampak positif dan negatif suatu teknologi, menyadari adanya nilai yang dianut dalam masyarakat, kreatif dalam mencari masalah dan penyelesaian masalah; 2) dilakukan kegiatan eksplorasi misalnya dengan mengumpulkan data, observasi, interhasil, prediksi, mengukur dan membuat model. Data eksplorasi ini kemudian didiskusikan, dari diskusi dan pengenalan konsep-konsep lain yang berkaitan dengan fenomena yang diselidiki diperoleh ide konsep yang dipelajari sehingga terjadi pembentukan konsep pada peserta didik. Mungkin juga terjadi perubahan konsepsi apabila peserta didik sebelumnya telah memiliki konsepsi tertentu atau terjadi pembentukan konsep lain sebagai hasil 
diskusi; 3) Konsep yang telah terbentuk ini dapat diaplikasikan atau diekspansi pada situasi lain; dan 4) suatu hal penting sebelum pertemuaan berakhir, dosen perlu memberikan rangkuman atau ulasan tentang konsep-konsep yang benar sehingga tidak terjadi salah konsep di antara peserta didik.

Berpijak pada paparan teori di atas, pembelajaran sains-teknologimasyarakat merupakan suatu konsep belajar yang membantu dosen mengkaitkan materi atau konsep-konsep motor bakar yang diajarkan dengan situasi kehidupan nyata mahasiswa dan mendorong mahasiswa membuat hubungan antara pengetahuan yang dimilikinya dengan penerapan dalam kehidupan mereka sebagai anggota keluarga dan masyarakat. Pendekatan STM memiliki beberapa keunggulan dalam proses pembelajaran antara lain, (1) masalah atau isu yang terkait dengan konsep yang sedang di pelajari diidentifikasi oleh siwa, (2) keterlibatan mahasiswa lebih aktif, karena meraka harus mncari informasi yang berguna untuk memecahkan masalah, (3) proses belajar dapat melampaui apa yang tertera dalam kurikulum, (4) proses pembelajaran dapat melampaui batas waktu, ruang kelas, dan sekolah.

Penerapan STM dalam pembelajaran motor bakar dapat dilakukan dengan menitikberatkan pada penyelesaian masalah dan proses berpikir dengan menerapkan konsep-konsep yang diperoleh di sekolah dan pada situasi di luar sekolah yakni yang ada dimasyarakat dengan strategi memunculkan isu sosial atau masalah, dengan demikian mahamahasiswa mengenali teknologi yang ada disekitarnya.

\section{Hakikat Model Pembelajaran Konvensional}

Pendekatan konvensional merupakan pendekatan pembelajaran yang biasa dilakukan dosen dalam proses belajar mengajar di dalam kelas. Pada pembelajaran konvensional, proses belajar mengajar lebih sering diarahkan pada "aliran informasi" atau "trannsfer" pengetahuan dari dosen ke mahasiswa. Konsep yang diterima mahasiswa hampir semuanya berasal dari "apa kata dosen". Dosen menganggap belajar adalah semata-mata mengumpulkan atau menghafalkan fakta-fakta yang tersaji dalam bentuk informasi atau materi pelajaran. Proses pembelajaran cenderung hanya mengantarkan mahasiswa untuk mencapai tujuan untuk mengejar target kurikulum, sehingga proses pembelajaran di kelas memiliki ciri-ciri sebagai berikut. 1) dosen aktif, tetapi mahasiswa pasif, 2) pembelajaran berpusat pada dosen (teacher oriented), 3) transfer pengetahuan dari dosen pada mahasiswa dan 4) pembelajaran bersifat mekanistik.

Akibat dari pembelajaran tersebut mahasiswa menjadi terbiasa menerima apa saja yang diberikan oleh dosen tanpa mau berusaha menemukan sendiri konsep-konsep yang sedang dipelajari. Dosen akan merasa bangga ketika anak didiknya mampu menyebutkan kembali secara lisan (verbal) sebagian besar informasi yang terdapat dalam buku teks atau yang diberikan oleh dosen. Penekanan pembelajaran adalah diperolehnya kemampuan mengingat (memorizing) dan bukan kemampuan memahami (understanding).

Pembelajaran yang dilakukan oleh dosen masih berpegang pada teori tingkah laku (behavioristik). Teori ini didasari asumsi bahwa peserta didik (mahasiswa) adalah manusia pasif yang tugasnya hanya mendengarkan, mencatat dan menghafal, serta hanya melakukan respon terhadap stimulus yang datang dari luar (stimulusresponse). Mahasiswa akan belajar apabila dilakukan pembelajaran oleh dosen secara sengaja, teratur dan berkelanjutan. Tanpa upaya pembelajaran yang disengaja dan berkelanjutan maka mahasiswa tidak mungkin melakukan kegiatan belajar (Sudjana, 2004: 25). Belajar merupakan perubahan tingkah laku yang muncul sebagai respon individu terhadap stimulus yang datang dari luar (lingkungan). Mahasiswa di dalam belajar 
supaya disongsong dan dipersiapkan untuk dapat menerima bentukan dari luar. Semua mahasiswa dianggap individu yang sama, sehingga bila mahasiswa diberikan stimulus maka respon yang diberikan akan sama.

Dalam pendekatan konvensional, pola pembelajaran atau urutan sajian materi khususnya dalam pembelajaran motor bakar adalah, 1) pembelajaran diawali penjelasan singkat materi oleh dosen, mahasiswa diajarkan teori, defenisi, teorema yang harus dihafal, 2) pemberian contoh soal dan 3) diakhiri dengan latihan soal. Dalam fase latihan soal, mahasiswa diberi kesempatan untuk melakukan pelatihan dan pemberian umpan balik terhadap keberhasilan mahasiswa. Pada fase ini pula, dosen jarang memberikan kesempatan kepada mahasiswa untuk menerapkan pengetahuan dan keterampilannya yang dipelajarinya ke dalam situasi kehidupan nyata. Dalam pembelajaran konvensional metode ceramah merupakan pilihan utama sebagai metode pembelajaran.

Dengan pola pembelajaran seperti di atas, dosen akan mengontrol secara penuh materi pelajaran serta metode penyampaiannya. Akibatnya, proses pembelajaran di kelas menjadi proses mengikuti langkah-langkah, aturan-aturan serta contoh-contoh yang diberikan oleh dosen. Di bidang penilaian, seorang mahasiswa dinilai telah menguasai materi pelajaran jika mampu mengingat dan mengaplikasikan langkah-langkah, aturan-aturan serta contoh-contoh yang telah diberikan oleh dosen.

\section{Hasil Belajar Motor Bakar}

Menurut Witherington (dalam Sukmadinata, 2003: 155) bahwa, belajar merupakan perubahan dalam kepribadian, yang dimanifestasikan sebagai pola-pola respons yang baru berbentuk ketrampilan, sikap, kebiasaan, pengetahuan dan kecakapan.

Penguasaan hasil belajar oleh seseorang dapat dilihat dari perilakunya, baik perilaku dalam bentuk penguasaan pengetahuan, sikap mental, keterampilan berpikir maupun keterampilan motorik. Di sekolah hasil belajar ini dapat dilihat dari penguasaan mahasiswa akan mata pelajaran yang ditempuhnya. Jadi hasil belajar adalah penguasaan pengetahuan atau keterampilan yang dikembangkan melalui mata pelajaran, lazimnya ditunjukkan dengan nilai tes atau angka nilai yang diberikan dosen. Hasil belajar dapat dioperasionalkan dalam bentuk indikator-indikator berupa nilai rapor, angka kelulusan, predikat keberhasilan, dan semacamnya (Azwar, 2002 : 164).

Hasil belajar menunjuk pada prestasi belajar dan prestasi belajar merupakan indikator adanya dan derajat perubahan tingkah laku mahasiswa (Hamalik. 2003: 159). Pengukuran terhadap terhadap hasil belajar dengan cara tertentu sesuai dengan maksud dan tujuan pengukuran tersebut dan dirancang dengan model desain evaluasi. Berdasarkan teori ini, hasil belajar diartikan sebagai perubahan tingkah laku mahasiswa secara nyata dan maksimal setelah dilakukan proses belajar mengajar yang sesuai dengan tujuan pembelajaran. Hasil belajar mata kuliah motor bakar adalah perubahan tingkah laku secara nyata dan makasimal sesuai dengan tujuan pengajaran yang dimiliki mahasiswa setelah dilakukan kegiatan proses belajar mengajar. Perubahan tingkah laku nyata ini merupakan perubahan yang cenderung menetap dari ranah kognitif, afektif, dan sikomotorik. Ketiganya dinyatakan dalam satu bentuk nilai atau angka keberhasilan. Perubahan tingkah laku yang diamati, yaitu: kemampuan yang berhubungan dengan berpikir, mengetahui, dan memecahkan masalah seperti pengetahuan komprehensif, aplikatif, sintesis, analisis, dan pengetahuan evaluatif.

\section{Pengertian Bakat Mekanik}

Bennett dan Butler (dalam Mukhadis 2003: 43) mendefinisikan bakat mekanik sebagai kemampuan potensial pebelajar dalam menerima dan memahami hubungan prinsip-prinsip dan kaidahkaidah prosedural yang mendasari cara kerja peralatan permesinan, peralatan listrik serta peristiwa alamaiah. Sukardi (2005:78) mengatakan bahwa, bakat 
mekanik adalah kemampuan seseorang dapat mengungkap prinsip-prinsip umum fisika, pada saat seseorang melihatnya dalam kejadian sehari-hari serta pemahaman seseorang terhadap hukumhukum yang mendasari alat-alat, mesinmesin dan gerakan-gerakan yang sederhana. Kedua pendapat ini nampak secara prinsip tidak menunnjukkan perbedaan terlalu jauh. Keduanya menunjukkan bahwa, bakat mekanik itu adalah salah satu komponen kognitif, yang menyatakan tingkat kemampuan atau potensi dasar yang dimiliki seseorang dapat mengungkap prinsipprinsip umum fisika, pada saat seseorang melihatnya dalam kejadian sehari-hari serta pemahaman seseorang terhadap hukum-hukum yang mendasari alat-alat, mesin-mesin dan gerakan-gerakan yang sederhana. Tingkat kemampuan ini dinyatakan dengan skor yang diukur menggunakan tes bakat mekanik.

Mukhadis (2003: 70), menyebutkan secara rinci aspek-aspek pengukuran bakat mekanik, yaitu: 1) pemahaman terhadap prinsip dan hukum perbandingan jumlah putaran konstruksi dua buah roda atau lebih pada suatu perkakas mesin/ listrik, 2) pemahaman terhadap prinsip dan hukum arah putaran konstruksi dua buah roda atau lebih pada suatu perkakas mesin/ listrik, 3) pemahaman terhadap prinsip dan hukum pembebanan tarik pada suatu perkakas mesin/listrik, 4) pemahaman terhadap prinsip dan hukum pembebanan tekanan pada suatu perkakas mesin/listrik, 5) pemahaman terhadap prinsip dan hukum pembebanan geser atau bergetar pada suatu perkakas mesin/listrik, 6) pemahaman terhadap prinsip dan hukum kesetimbangan pada suatu perkakas mesin/listrik, 7) pemahaman terhadap prinsip dan hukum momen dan usaha pada suatu perkakas mesin/listrik, 8) pemahaman terhadap prinsip dan hukum gerak (beraturan, tak beraturan pada jatuh bebas) pada suatu perkakas mesin/ listrik, dan 9) pemahaman terhadap prinsip dan hukum menentukan isi dan tekanan pada suatu perkakas mesin/ listrik.
Sebagai contoh diberikan sebuah bentuk tes untuk mengukur bakat mekanik seseorang pada aspek pemahaman terhadap prinsip dan hukum kesetimbangan pada suatu perkakas, seperti ditunjukkan pada gambar 2.1.

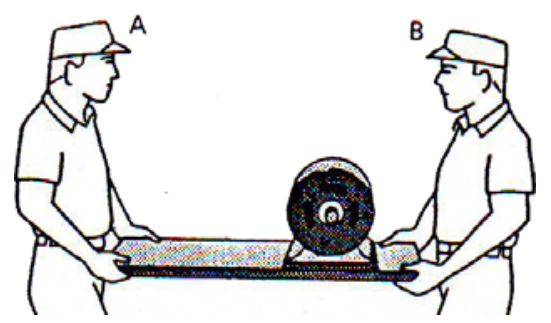

Gambar 1. Kesetimbangan beban. Sumber : Anastasi , 1998 : 381

Berdasarkan paparan teori di atas, bakat mekanik dalam penelitian ini diartikan sebagai kemampuan potensial yang dimiliki setiap individu mahasiswa dalam memahami cara kerja alat, mesin dan gerakan sederhana. pada ranah psikomotor. Subjek yang diukur bakat mekaniknya ditunjukkan dengan diagramdiagram mekanis atau situasi-situasi yang berhubungan dengan persoalan mekanis berupa operasional gerakan-gerakan sederhana, perkakas-perkakas sederhana, dan peralatan sederhana.

\section{METODOLOGI}

Penelitian ini dilaksanakan di jurusan teknik mesin Politeknik Negeri Bali pada tahun ajaran 2007/2008, dengan sampel 46 orang diambil secara random sampling dari mahasiswa semester IV jurusan teknik mesin. Penelitian ini melibat satu variabel bebas yaitu pendekatan pembelajaran, satu kovariabel (variabel bersama) yaitu bakat mekanik, dan satu variabel terikat yakni hasil belajar motor bakar. Pendekatan yang digunakan yaitu pendekatan eksperimen semu (quasy experiment) dengan rancangan kelompok control hanya postest saja (The Posttest-Only Control Group Design), seperi gambar 2.

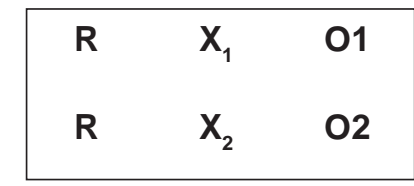

Gambar 2. Rancangan Eksperimen The Posttest-Only Control Group Design (Campbel and Stanley,1963 : 25) 
Keterangan:

$\mathrm{X}_{1}=$ Perlakuan pmbelajaran dengan pendekatan STM

$\mathrm{X}_{2}=$ Perlakuan pembelajaran dengan pendekatan konvensional

$\mathrm{O}=$ Pengamatan akhir (Post-test) berupa hasil belajar belajar motor bakar.

Kelompok eksperimen dikenai perlakuan pembelajaran dengan mengikuti pendekatan STM dan kelompok kontrol dikenai perlakuan pembelajaran konvensional dalam jangka waktu tertentu, kemudian kedua kelompok dikenai pengukuran yang sama. Perbedaan hasil pengukuran yang timbul dianggap bersumber dari variabel perlakuan.

Perlakuan antara kelompok eksperimen dan kelompok control mengaju kepada Rencana Pelaksanaan Pembelajara (RPP) pada masing-masing materi pembelajaran yang diberikan.

Deskripsi data mengenai hasil belajar motor bakar, masing-masing dideskripsikan dengan tabel distribusi frekuensi dan histogram. Kualifikasi bakat mekanik, dianalisis secara deskriptif atas dasar data skor idial ( $\mathrm{Mi}=$ ratarata ideal) dan (Sdi) =simpangan baku ideal.

Pengukuran bakat mekanik dilakukan dengan menggunakan 30 butir soal dengan kreteria penilain: skor 1 untuk setiap jawaban benar dan skor 0 untuk setiap jawaban yang salah. Maka skor maksimum dan minimum ideal menjadi 30 dan 0 . Skor bakat mekanik diklasifikasikan menurut interval: $20 \leq$ skore $\leq 30$ (tinggi), $10 \leq$ skore $<20$ (sedang), dan 0 $\leq$ skore $<10$ (rendah).

Hasil belajar motor bakar diukur denagn menggunakan 36 butir soal dengan kreteria penilain: skor 1 untuk setiap jawaban benar dan skor 0 untuk setiap jawaban. Maka skor maksimum dan minimum ideal menjadi 36 dan 0. Skor hasil bakat mekanik diklasifikasikan menurut interval: $24 \leq$ skore $\leq 36$ (tinggi), $12 \leq$ skore $<24$ (sedang), dan 0 $\leq$ skore $<12$ (rendah).

Data dianalisis dengan menggunakan statistik deskriptif dan infrensial. Hipotesis yang diuji kebenarannya yaitu: 1) rata-rata skor hasil belajar motor bakar mahasiswa yang diajar dengan pendekatan STM lebih tinggi dibandingkan dengan mahasiswa yang diajar dengan pendekatan konvensional, dan 2) setelah diadakan pengendalian terhadap variabel bakat mekanik, rata-rata hasil belajar motor bakar mahasiswa yang diajar dengan pendekatan STM lebih tinggi dibandingkan dengan mahasiswa yang diajar dengan pendekatan konvensional. Hipotesis pertama di uji perbedaan dua rata-rata dengan uji t, sedangkan hipotesis kedua diuji menggunakan uji $\mathrm{F}$ satu jalur dengan pendekatan anakova.

\section{HASIL DAN PEMBAHASAN}

Analisis dekriptif memberikan hasil, yaitu: 1) skor rata-rata bakat mekanik pada kelompok eksperimen dan kontrol yaitu: 23, 00 dan 22.41 keduanya berada pada kategori tinggi; 2) skor hasil belajar motor bakar mahasiswa yang diberikan perlakuan pembelajaran dengan pendekatan STM: maksimum 36 , minimum 28 , rentang atau range 8 , simpangan baku 2.059, dan rata-rata 32,36 terkategori tinggi; 3) skor hasil belajar mahasiswa yang diberikan perlakuan pembelajaran dengan pendekatan konvensional: maksimum 28, minimum 19, rentang atau range 9 , simpangan baku 2.115, dan rata-rata 21.96 terkategori sedang.

Hasil Uji Hipotesis menunjukkan bahwa: hasil perhitungan uji t menunjukan bahwa nilai $t_{\text {hitung }}$ sebesar 16.145, Harga kritis $t_{\text {tabel }}$ untuk $\mathrm{db}=42$ dan taraf signifikansi $\mathrm{a}=0,05$ yaitu 1,884. Harga $t_{\text {hitung }}$ lebih besar dari nilai kritis, akibatnya $\mathrm{H}_{0}$ ditolak dan $\mathrm{H}_{1}$ diterima. Dengan demikian dapat disimpulkan bahwa hasil belajar kelompok eksperimen secara signifikan lebih tinggi daripada hasil belajar kelompok kontrol. Hal ini berarti pembelajaran pendekatan Sains-Teknologi-Masyarakat secara signifikan berpengaruh terhadap hasil belajar motor bakar mahamahasiswa. Analisis uji beda sebelum bakat mekanik dikendalikan didapatkan haraga $\mathrm{F}$ sebesar 260,653 dan signifikan. Sedangkan hasil anakova mendapatkan harga $F_{\text {hitung }}=248.338$ $>$ nilai $F_{\text {tabel }}$ sebesar 4.07 pada taraf signifikan

$=5 \%$ sehingga $\mathrm{H}_{0}$ ditolak, akibatnya hipotesis alternatif $\left(\mathrm{H}_{1}\right)$ diterima.

Nilai $\mathrm{F}$ sebelum bakat mekanik dikendalikan lebih besar dari nilai $F$ setelah bakat mekanik dikendalikan. Kondisi ini mengidentifikasikan bahwa bakat mekanik cukup besar pengaruhnya terhadap hasil belajar motor bakar. Bennett dan Butler (dalam Mukhadis 2003: 43) bakat bakat mekanik sebagai 
kemampuan potensial pebelajar dalam menerima dan memahami hubungan prinsipprinsip dan kaidah-kaidah prosedural yang mendasari cara kerja peralatan permesinan, peralatan listrik serta peristiwa alamaiah.

Azwar (2002 : 164) menegaskan bahwa, keberhasilan dalam belajar dipengaruhi oleh banyak faktor yang bersumber dari dalam (internal) maupun dari luar (eksternal) diri individu. Faktor internal terdiri dari faktor fisiologis dan psikologis. Faktor psikologis meliputi faktor intelektif dan nonkognitif. Faktor kognitif salah satu diantranya adalah bakat mekanik.

Dengan demikian ditinjau dari bakat mekanik, setelah dilakukan pengendalian variabel bakat mekanik rata-rata skor hasil belajar motor bakar mahasiswa yang diajar dengan menggunakan pendekatan STM secara signifikan lebih tinggi dibandingkan mahasiswa yang diajar dengan menggunakan pendekatan konvensional. Hasil belajar mahasiswa yang diajar dengan menggunakan pendekatan STM lebih tinggi dibanding dengan hasil belajar mahasiswa yang diajar dengan menggunakan pendekatan STM setelah dilakukan pengendalian variabel bakat mekanik. Artinya, pendekatan STM tetap berpengaruh terhadap hasil belajar mahasiswa dalam pelajaran motor bakar walaupun variabel bakat mekanik telah dikendalikan. Kondisi ini mengidentifikan bahwa, bakat mekanik tidak berkontribusi terhadaf efektivitas penerapan pendekatan STM dalam pembelajaran motor bakar. Terjadinya perbedaan hasil belajar pada mahasiswa yang diajar menggunakan pendekatan STM dengan mahasiswa yang diajar dengan pendekatan konvensional memang disebabkan pengaruh penerapan pendekatan STM dalam pembelajaran.

Menurut Poedjiadi (2005:123) STM sebagai upaya mendekatkan mahasiswa kepada obyek yang dibahas. Pengajaran yang menjadikan benda yang dibahas secara langsung dihadapkan kepada mahasiswa atau mahasiswa di bawa langsung ke alam sekitarnya, disebut sebagai onstention. Mariana (2001: 29), mengatakan dalam belajar semacam ini mahasiswa mencari hubungan kesamaan (similarity relation) sehingga memperoleh kelompok berdasarkan konsep dan teori yang telah dimiliki dan memperoleh pola-pola berdasarkan pengamatan. Pada hakekatnya pembelajaran sains dengan pendekatan STM, di samping memperoleh pengalaman fisik terhadap obyek dalam proses pembelajarannya, mahasiswa juga memperoleh pengalaman atau terlibat secara mental. Pengalaman fisik, artinya melibatkan mahasiswa atau mempertemukan mahasiswa dengan obyek pembelajaran. Pengalaman mental yang dimaksudkan di sini, adalah memperhatikan imformasi awal yang telah ada pada diri mahasiswa, dan memberikan kebebasan kepada mahasiswa untuk menyusun sendiri-sendiri informasi yang diperolehnya. Karena kondisi inilah kelompok mahasiswa yang diajar mennggukan pendekatan STM hasil belajarnya cenderung lebih tinggi dibandikan dengan mahassiwa yang diajar denga pendekatan konvensional.

\section{E. PENUTUP}

\section{Simpulan}

Berdasarkan hasil dan pembahasan yang telah dikemukakan didepan dapat dirumuskan beberapa simpulan: 1) hasil belajar motor bakar pada kelompok yang diajar dengan pendekatan STM secara signifikan lebih tinggi daripada hasil belajar kelompok yang diajar dengan pendekatan konvensional. Pembelajaran dengan pendekatan STM secara signifikan berpengaruh terhadap hasil belajar motor bakar, 2) setelah dilakukan pengendalian variabel bakat mekanik rata-rata skor hasil belajar motor bakar mahasiswa yang diajar dengan menggunakan pendekatan STM secara signifikan lebih tinggi dibandingkan mahasiswa diajar dengan menggunakan pendekatan konvensional. Pendekatan STM tetap berpengaruh terhadap hasil belajar motor bakar walaupun variabel bakat mekanik telah dikendalikan; dan 3) tidak ada kontribusi dari bakat mekanik kepada pengaruh penggunaan pendekatan pembelajaran terhadap hasil belajar motor bakar. 


\section{Implikasi dan Saran}

Implikasi yang dapat diambil dari hasil penelitian ini adalah meningkatkan hasil belajar motor bakar dapat diupayakan dengan mengiplementasikan pendekatan
STM pada pembelajaran motor bakar di jurusan teknik mesin. Proses pembelajaran berpendekatan STM diterapkan mengikuti dengan sintaks pembelajaran seperti yang disajikan pada tabel 2.

Tabel 1 Sintak Pembelajaran Sains-Teknologi-Masyarakat

\begin{tabular}{|c|c|c|}
\hline No & Aktivitas Dosen & Aktivitas Mahasiswa \\
\hline 1 & $\begin{array}{l}\text { Tnvitasi } \\
\text { Orientasi siswa pada masalah } \\
\text { - Memotivasi mahasiswa dengan cara tanya } \\
\text { jawab, yang berkaitan dengan materi dalam } \\
\text { kehidupan sehari-hari } \\
\text { - Menyapaikan tujuan pembelajaran }\end{array}$ & $\begin{array}{l}\text { Mahasiswa menjawab pertanyaan dosen } \\
\text { Mahasiswa mempersiapkan logistik yang } \\
\text { diperlukan }\end{array}$ \\
\hline 2 & $\begin{array}{l}\text { Ekplorasi } \\
\text { Mengorganisasikan Mahasiswa untuk Belajar } \\
\text { - Mencari isu relevan di masyarakat sesuai } \\
\text { dengan topik sedang dibahas untuk dijadikan } \\
\text { pemicu mahasiswa mengungkapkan hal-hal } \\
\text { yang telah diketahuinya } \\
\text { - Membagikan lembar kerja yang berisi } \\
\text { pertanyaan-pertanyaan yang sesuai dengan } \\
\text { sains dan teknologi yang ada masyarakat } \\
\text { - Membimbing mahasiswa dalam } \\
\text { menyelesaikan masalah yang termuat pada } \\
\text { lember kerja } \\
\text { - Mengajukan pertanyaan tentang apa yang } \\
\text { dipikirkan mahasiswa untuk dapat } \\
\text { menekplorasi pengetuan awalnya. }\end{array}$ & $\begin{array}{l}\text { Mahasiswa mengerjakan lembar kerja } \\
\text { yang dibagikan } \\
\text { Mahasiswa menjawab pertanyaan } \\
\text { berkonsultasi dengan dosen berkaitan } \\
\text { masalah yang terdapat pada lembar kerja } \\
\text { kerja } \\
\text { Mahasiswa menajwab pertanyaan yang di } \\
\text { ajukan dosen sesuai dengan } \\
\text { pengetuannya masing-masing. }\end{array}$ \\
\hline 3 & $\begin{array}{l}\text { Pengajuan Ekplanasi dan solusi } \\
\text { Pengembangan } \\
\text { - Meminta mahasiswa untuk membuat } \\
\text { rangkuman dan kesimpulan tentang } \\
\text { konsep yang telah dibahas, sumberkonsep, } \\
\text { dan pandangan masyarakat di sekitar. }\end{array}$ & $\begin{array}{l}\text { Mahasiswa rangkuman dan kesimpulan } \\
\text { tentang konsep yang telah dibahas, } \\
\text { sesuai dengan isu teknologi masyarakat } \\
\text { di sekitar. }\end{array}$ \\
\hline 4 & $\begin{array}{l}\text { Tindak lanjut } \\
\text { - Mengevaluasi produk pembelajaran } \\
\text { - Memberikan penguatan kepada mahasiswa }\end{array}$ & $\begin{array}{l}\text { Mahasiswa menyimpulkan materi yang } \\
\text { dipelajari untuk disampaikan kepada } \\
\text { dosen. }\end{array}$ \\
\hline
\end{tabular}

ar motor bakar maupun dapat disarankan untuk ısikan Pendekatan Sainsiyarakat (STM) dalam es belajar mengajar, pembelajaran alternatif neningkatkan prestasi wa. Dalam pembelajaran ihasiswa pendekatan 'ang dibahas, dengan siswa dapat memperoleh fisik terhadap ojek, juga memperoleh tu terlibat secara mental. sik, artinya melibatkan 
mahasiswa dengan ojek pembelajaran. Pengalaman mental yang dimaksudkan di sini adalah memperhatikan imformasi awal yang telah dimiliki mahasiswa untuk menyusun sendiri imfomasi yang diperoleh.

Kepada pengambil kebijakan dapat disarankan untuk, memasukan STM ke dalam pedoman pelaksanaan proses belajar mengajar sebagai salah satu model pembelajaran alternatif

Kepada para peneliti dan pemerhati penelitian pendidikan, dalam upaya meningkatkan hasil belajar mahasiswa disarankan beberapa hal sebagai berikut: (a) Melaksanakan penelitian Ianjutan dengan melibatkan model pembejaran

\section{DAFTAR PUSTAKA}

Anastasi, Anne, Susana Urbina. 1998. Tes Psikologi, Psychological Testing 7e, Edisi Bahasa Indonesia Jilid 1, Alih Bahasa: Drs Robertus Hariono S. Iman, MA. Jakarta: PT Prenhallindo

Azwar Saifudin. 2002. Pengantar Psikologi Intelegensi. Yogyakarta: Pustaka Pelajar

Adnyana Budi, I Putu. 2004. Pengembangan Model Pembelajaran Kooperatif Bermodul yang Berwawasan STM dan Pengaruh Implementasinya terhadap Hasil Belajar Biologi Mahasiswa SMA di Singaraja. Disertasi (tidak diterbitkat) Universitas Negeri Malang.

Abbas, Nurhayati. 2005. Penerapan Model Pembelajaran Berdasarkan Basis Masalah Pada pembelajaran Matematika. Makalah. http://www.depdiknas.go.id/Jurnal/40/ p.1. diakses tanggal 10 Juni 2006.

Barret, Jim. 2004. Test Yourself. Advanced Aptitude Test. Panduan Sukses Menghadapi Tes Bakat. Solo : Tiga Serangkai

Campbell, Donald T. \& Julian C, Stanley. 1963. Experimental and Quasi Experimental Designs for Research. Chicago: Rand Mc.Nally College Publishing Company.

Dantes I Nyoman, 2001, Kumpulan Makalah, Singaraja: Departemen Pendidikan dan Kebudayaan IKIP Negeri Singaraja

Darma I Ketut. 2007. "Pengaruh Model Pembelajaran Konstruktivisme Terhadap dengan strategi pembelajaran lainnya seperti CTL, kooperati, atau dengan pembelajaran interaktif, (b) Melaksanakan penelitian tindakan kelas pada setiap sub pakok bahasan motor bakar untuk mendapatkan model pembelajaran STM yang ideal untuk diterapkan pada mata kuliah motor bakar di Politeknik, (c) Melaksanakan penelitian tindakan kelas mata kuliah motor bakar dengan melibatkan pendekatan STM dengan mengambil variabel lain dari bakat mekanik sebagai kovariabel seperti IQ, minat, motivasi latar belakang pendidikan, bekal ajar dan lain sebagainya, untuk melihat pengaruh secara murni pendekatan STM terhadap hasil belajar motor bakar.

Prestasi Belajar Matematika Terapan Pada Mahasiswa Politeknik Negeri Bali Di Tinjau Dari Motivasi Berprestasi".Jurnal. Teknodik No. 22/XI/TEKNODIK/DESEMBER/2007

Fajar, Arnie. 2004. Prtofolio: Dalam Pembelajaran IPS. Bandung: PT Remaja Roesdakarya.

Hudoyo, H. 1992. Strategi Belajar Mengajar Matematika. Malang: IKIP Malang Selatan. www.Depdiknas.90.id./jurnal diakses tanggal 15 Mei 2006

Hanbury, L. 1996. Constructivism: So What? In J. Wakefield and L. Velardi (Eds.). Celeberating Mathematics Learning (pp.3 8). Melbourne: The Mathematical Assciation of Victoria.

Hamalik Oemar. 2003. Kurikulum dan Pembelajaran. Jakarta: Bumi Aksara

Hamzah. 2005. Pembelajaran Matematika menurut Teori Belajar Konstruktivisme.Makalah. http:// www.depdiknas.go.id/Jurnal [akses 24 juni 2006]

Mayer, R.E. 1996. "Feedback in Learning". Dalam E. De Corte \& F.E. Winert (Eds). International Encyclopedia Developmental and Intructional Psycology (hlm 396-398). New York: Pergamon

Mariana, Alit. 2001. Kecendrungan Pendidkan IPA, Pendekatan Sains, Teknologi dan Masyarakat. Depdiknas. Dirjen Pendidikan Dasar dan Menengah. Pusat Pengembangan 
Penataran Guru IPA

Mukhalis, Amat. 2003. Pengorganisasianlsi

Pembelajaran Tipe Prosedural (Kajian

Empirik Sekolah Menengah kejuruan

Rumpun Teknologi). Malang: Universitas negeri Malang.

Nurhadi, dkk. 2004. Pembelajaran Kontekstual dan Penerapannya Dalam KBK. Malang: Universitas Negeri Malang

Poedjiadi, Anna. 2005. Sains Teknologi Masyarat: Model Pembelajaran Kontekstual Bermuatan Nilai. Bandung: Remaja Rosdakarya

Rumansyah Dan Yudha Irhasyuarna. 2003. Prospek Penerapan Pendekatan Sains Teknologi Masyarakat (STM) Dalam Pembelajaran Kimia Di Kalimantan

Sukmadinata, Nana, S. 2003. Landasan Psikologi Proses Pendidikan. Bandung: PT Remaja Rosdakarya.

Sudjana, Nana. 2004. Penilaian Hasil Proses Belajar Mengajar. Bandung: PT. Remaja Rosdakarya

Subariah Sri. 2005 “Pengembangan Rancangan Mata Kuliah Geometri Menggunakan Pendekatan Pembelajaran Konstruktivisme Pada Program Studi Pendidikan Matematika
FKIP Universitas Mataram" Jurnal Pendidikan dan Kebudayaan. No 0.053. tahun Ke -11. Maret 2005

Sukardi, Dewa Ketut dan Kusmawati, Nila Desak P. E. 2005. Analisis Tes Bakat. Bogor: Ghalia Indonesia.

Tasker, R. 1992. Effective Teaching: What Can a Constructivist View of Learning Offer. The Australian Science Teacher JouTyrnal. 38 (1), 25 - 34.

Tytler, R. 1996. Constructivism and Conceptual Change View of Learning in Science. Majalah Pendidikan IPA: Khasanah Pengajaran IPA. Bandung: IMAPIPA.

Wheatley, G.H. 1991. Constructivist Perspective on Science and Mathematics Learning. Science Education Journal. 75 (1), 9 - 21.

Yager, R.E. 1993. STS: Most Pervasive and Most Radical of Reform Approaches to "Science" Education. Dalam R.E. Yager (Ed) What Research Says to the Science Teacher, Volume Seven: The Science Technology, Society Movemen. Washington D.C: NSTA

Zamroni. 2000. Pengantar Pengembangan Teori Sosial. Yogyakarta: Tiara wacana 